\title{
Gelsolin-related Amyloidosis \\ Identification of the Amyloid Protein in Finnish Hereditary Amyloidosis as a Fragment of Variant Gelsolin
}

C. P. J. Maury

The Fourth Department of Medicine, University of Helsinki, Helsinki, Finland

\begin{abstract}
The Finnish type of familial amyloidosis is a systemic disease characterized by progressive cranial neuropathy, corneal lattice dystrophy, and distal sensimotor neuropathy. Amyloid fibrils were isolated from the kidney and heart of a patient with Finnish amyloidosis. After solubilization, the amyloid proteins were fractionated by gel filtration and purified by reverse-phase HPLC. Complete amino acid sequence analyses show that the two amyloid components obtained are fragments of gelsolin, an actin-modulating protein occurring in plasma and the cytoskeleton. The larger component represents residues 173-243 and the minor component residues 173-225, respectively, of mature gelsolin. When compared with the predicted primary structure of human gelsolin a single amino acid substitution is present in amyloid: at position 15 of the amyloid proteins an asparagine is found instead of an aspartic acid residue at the corresponding position (187) in gelsolin. Antibodies to a dodecapeptide of the amyloidogenic region of gelsolin specifically stain the tissue amyloid deposits in Finnish hereditary amyloidosis. The results show that the amyloid subunit protein in Finnish hereditary amyloidosis represents a new type of amyloid that is derived from an actin filament-binding region of a variant gelsolin molecule by limited proteolysis. (J. Clin. Invest. 1991. 87:1195-1199.) Key words: familial amyloid polyneuropathy type IV • corneal lattice dystrophy $\bullet$ amyloidogenesis $\bullet \boldsymbol{\beta}$-fibrillosis $\bullet$ anti-gelsolin antibodies
\end{abstract}

\section{Introduction}

Familial amyloid polyneuropathy (FAP) ${ }^{1}$ syndromes are autosomal dominant disorders characterized by extracellular deposits of fibrillar protein with crossed $\beta$-pleated sheet conformation and a clinical syndrome of polyneuropathy. The FAP syndromes differ from each other with respect to distribution and degree of involvement of affected nerves and organs, age of onset, and ethnic origin. The Finnish type of familial amyloidosis (FAP type IV or Meretoja amyloidosis; McKusick No. $105120)$ is a systemic disease characterized by a distinct clinical

Address correspondence to C. P. J. Maury, M.D., Associate Professor of Medicine, Fourth Department of Medicine, University of Helsinki, Unioninkatu 38, SF-00170 Helsinki, Finland.

Received for publication 3 August 1990 and in revised form 24 October 1990.

1. Abbreviation used in this paper: FAP, Familial amyloid polyneuropathy.

J. Clin. Invest.

(C) The American Society for Clinical Investigation, Inc. 0021-9738/91/04/1195/05 \$2.00

Volume 87, March 1991, 1195-1199 picture involving progressive cranial neuropathy, corneal lattice dystrophy, and distal sensimotor neuropathy (1). In heterozygous patients, the disease has a late onset and is slowly progressive. By the age of $20 \mathrm{yr}$, corneal dystrophy is usually manifested, and by the age of $40 \mathrm{yr}$ most patients have developed cranial neuropathy. Skin, renal, and cardiac manifestations also occur. In the rare, presumptively homozygous patients the disease has a more severe course characterized by renal insufficiency (2). By the end of the 1970 s more than 300 cases had been recorded in Finland (3). The disease is, however, not limited to Finland. Cases have also been described from the United States (4-6), Denmark (7), and the Netherlands (8).

The clinically different expression of the Finnish FAP, as compared with the FAP types I, II, and III and related syndromes (9), has raised the possibility of a unique amyloid fibril protein in this disease. Indeed, we showed that the amyloid fibril protein in Finnish FAP is different from all amyloid proteins identified so far, showing amino acid homology with gelsolin, an actin-modulating protein (10). The gelsolin nature of the amyloid in Finnish FAP was subsequently confirmed (11). The amyloid proteins accumulating in the kidney and heart have now been isolated, purified, and subjected to extensive structural studies. It is shown that the two major accumulating amyloid proteins are fragments of gelsolin in the regions of amino acids 173-243 and 173-225, respectively. At position 15 of the amyloid proteins an asparagine was found instead of the predicted aspartic acid residue in gelsolin (position 187; reference 12). A point mutation in the gelsolin gene causing the expression of the mutant asparagine- 187 gelsolin molecule in Finnish FAP was recently reported from this laboratory (13).

\section{Methods}

Isolation and fractionation of amyloid. Amyloid was isolated from autopsy samples of the kidney and the heart of a 71-yr-old man with Finnish hereditary amyloidosis. In the kidney the amyloid was primarily localized to the glomeruli; small amounts were also present in the larger blood vessels and the interstitium. In the cardiac tissue the amyloid was found in the arterial walls and to some extent in the perivascular tissue. For control purposes, Congo-red negative renal and splenic autopsy tissues were subjected to the same extraction procedure as the amyloid tissue. The renal amyloid was isolated by water extraction as described previously (10). For the isolation of cardiac amyloid formic acid extraction was used (14); after 11 saline washings, the sediment was sonicated in $75 \%$ formic acid (final concentration) for $1 \mathrm{~h}$ followed by centrifugation at $12,000 \mathrm{rpm}$ for $1 \mathrm{~h}$. The supernatants were lyophilized and dissolved in $6 \mathrm{M}$ guanidine- $\mathrm{HCl}$ buffered to $\mathrm{pH} 8.5$ with 0.5 $\mathrm{M}$ Tris- $\mathrm{HCl}$ containing $0.002 \mathrm{M}$ EDTA and $20 \mathrm{mM}$ dithiothreitol and incubated at $37^{\circ} \mathrm{C}$ for $3 \mathrm{~h}$ and then at room temperature overnight. After centrifugation, the supernatants were chromatographed on a Sephadex G-100 (Pharmacia Fine Chemicals, Uppsala, Sweden) column $(1.5 \times 98 \mathrm{~cm})$ using $5 \mathrm{M}$ guanidine- $\mathrm{HCl}$ with $1 \mathrm{M}$ acetic acid as eluent. The fractions were studied by gel electrophoresis (15-17\% SDSPAGE) and immunoblot (Western) techniques. The amyloid protein 


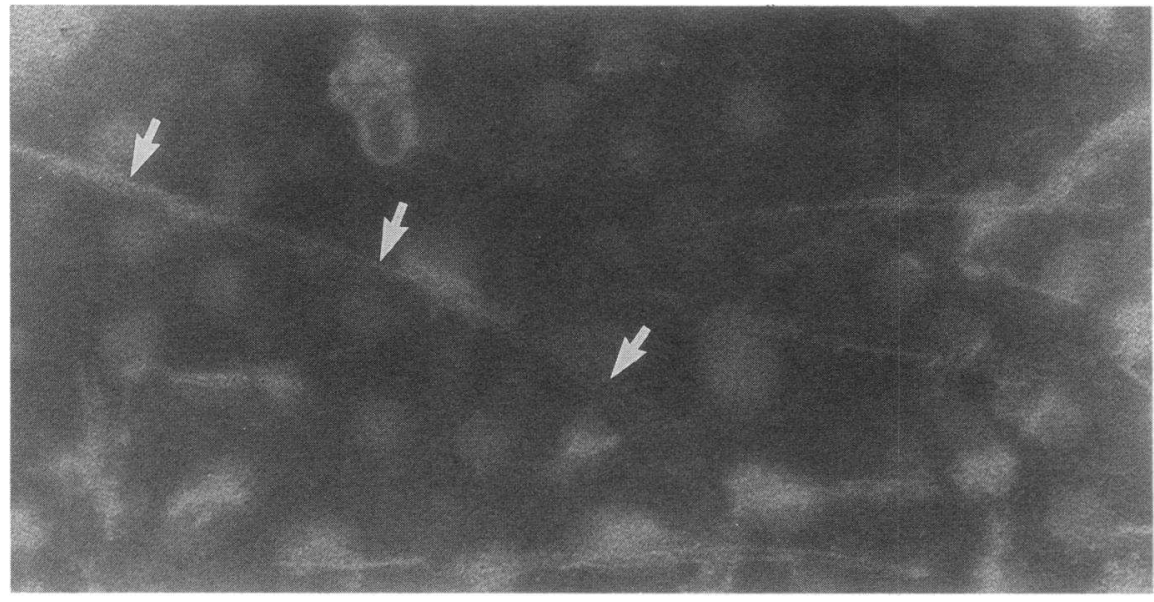

Figure 1. Electron micrograph of the amyloid fibril preparation isolated from Finnish hereditary amyloidosis kidney. Arrows indicate one of the fibrils. Negative staining. Original magnification, 130,000 . fraction was purified on reverse-phase HPLC (Beckman Instruments Inc., Fullerton, CA, System Gold, Programmable Solvent Module 126, SP 8450, UV/VIS detector, Spectra Physics Merck Hitachi D-2500 Chromato-Integration) using a Vydac $\mathrm{C}_{18}$ column and a $10-80 \%$ acetonitrile gradient in $0.1 \%$ trifluoroacetic acid.

Peptide fragmentation and separation on reverse-phase HPLC. The amyloid protein was alkylated and desalted and repurified on HPLC. Tryptic digestion (trypsin-TPCK, Sigma Chemical Co., St. Louis, MO) was carried out in $1 \%$ ammonium bicarbonate; incubation with $3 \%$ (wt/wt) of trypsin for $2 \mathrm{~h}$ at $37^{\circ} \mathrm{C}$ was followed by another addition (3\%) of the protease and continued incubation overnight at $37^{\circ} \mathrm{C}$. The released peptides were separated by reverse-phase HPLC using a Vydac $\mathrm{C}_{18}$ column equilibrated with $0.1 \%$ trifluoroacetic acid in water, with a linear gradient of acetonitrile (0-60\% in $60 \mathrm{~min})$. Digestion with endoproteinase Lys-C (sequencing grade, Boehringer-Mannheim, Mannheim, Germany) was carried out in $25 \mathrm{mM}$ Tris- $\mathrm{HCl}$ buffer, $\mathrm{pH} 8.5$; incubation with $3 \%$ (wt/wt) of enzyme for $2 \mathrm{~h}$ at $37^{\circ} \mathrm{C}$ was followed by another addition of the protease $(3 \%)$ and continued incubation overnight at $20^{\circ} \mathrm{C}$. Digestion with endoproteinase Asp-N (BoehringerMannheim) was carried out in $50 \mathrm{mM}$ sodium phosphate buffer, $\mathrm{pH}$ 8.0 for $16 \mathrm{~h}$ at $37^{\circ} \mathrm{C}$ using $10 \%$ (wt/wt) of enzyme and digestion with endoproteinase Glu-C (proteinase V8, Boehringer-Mannheim) was carried out in $25 \mathrm{mM}$ ammonium carbonate buffer, $\mathrm{pH} 7.8$ at $25^{\circ} \mathrm{C}$ overnight using $5 \%(w t / w t)$ of enzyme. The released peptides were separated by reverse-phase HPLC using a Vydac $C_{18}$ column equilibrated with $0.1 \%$ trifluoroacetic acid in water, with a linear gradient of acetonitrile $(0-70 \%)$ in $60 \mathrm{~min}$

Amino acid sequence analysis. The sequence analysis was performed by automated Edman degradation using a modified Applied Biosystems 477A/120A on-line pulsed liquid phase/gas sequencer in the gas phase mode. The NBRF Swiss-PROT sequence database was used for computer search of sequence homologies.

Electron microscopy. Amyloid specimens were placed on cupric grids and negatively stained by $1 \%$ phosphowolframic acid, $\mathrm{pH} 6.5$, and examined by a JEOL JEM 100 CX electron microscope.

Immunoperoxidase studies. Tissue samples from two patients with Finnish hereditary amyloidosis, two patients with secondary (amyloid A) amyloidosis, and two patients with myeloma-associated AL-lambda amyloidosis, as well as from four control subjects without amyloid, were studied. The samples included sections from the kidney (two Finnish hereditary amyloidosis, two amyloid A amyloidosis cases, and three cases with histopathologically normal renal tissue), heart (two Finnish hereditary amyloidosis cases, one myeloma-associated amyloidosis case, and one case with histopathologically normal cardiac tissue), liver (one amyloid A and one myeloma-associated amyloidosis case). Paraffin sections, $3 \mu \mathrm{m}$ thick, were deparaffinized, and endogenous peroxidase activity destroyed by incubating the sections with $0.5 \% \mathrm{H}_{2} \mathrm{O}_{2}$ in methanol for $30 \mathrm{~min}$ after which the sections were washed three times in $0.05 \mathrm{M}$ Tris/ $\mathrm{HCl}$ buffer diluted to $1: 10$ with physiologic saline (TBS) followed by incubation with normal swine serum, diluted 1:5, in TBS for $10 \mathrm{~min}$. The test sections were then incubated in moist chambers with the rabbit antisera diluted 1:5-1:500 for $30 \mathrm{~min}$ followed by three washings with $0.05 \mathrm{M}$ TBS. As a second layer swine immunoglobulin to rabbit immunoglobulin (Dakopatts, Glostrup, Denmark) diluted 1:30, were added and incubated for 30 min. After three washings with $0.05 \mathrm{M}$ TBS, rabbit peroxidase-antiperoxidase (Dakopatts), diluted 1:80, was added and incubated for $30 \mathrm{~min}$.

After three washings in $0.05 \mathrm{M}$ TBS, the sections were incubated for 5 min with $0.05 \%$ 3,3,-diaminobenzidinetetrahydrochloride (Sigma Chemical Co.) in $0.01 \% \mathrm{H}_{2} \mathrm{O}_{2}$. Control sections were treated similarly but the first antiserum was replaced with normal rabbit serum, antitransthyretin, anti-amyloid $P$, anti-immunoglobulin light chain, anti$\beta_{2}$-microglobulin (Dakopatts) and anti-amyloid A (Calbiochem-Behring Corp., La Jolla, CA) or the anti-gelsolin antibodies absorbed with the synthetic peptide used for immunization.

Antigelsolin antibodies were raised in rabbits using a synthetic dodecapeptide corresponding to gelsolin residues 231-242 ( $>95 \%$ pure, Multiple Peptide Systems, San Diego, CA) as antigen. The peptide was conjugated to keyhole limpet hemocyanin and administered $(200 \mu \mathrm{g}$ of peptide/injection) in Freund's complete adjuvant subcutaneously. Booster injections were given after 3 and $6 \mathrm{wk}$. The antibody titres were studied by enzyme immunoassay. In the absorption experiments 500 $\mu \mathrm{g}$ of uncoupled antigen were added to $200 \mu \mathrm{l}$ of antiserum and kept at room temperature for $2 \mathrm{~h}$ and then at $4^{\circ} \mathrm{C}$ overnight.

\section{Results}

The extracted amyloid fibril preparations were Congo-red positive and exhibited green dichroism when viewed under polar-

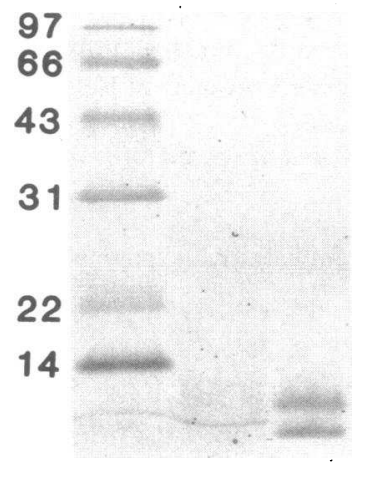

Figure 2. SDS-PAGE (15\%) of the amyloid protein fraction isolated from the kidney. Molecular weight markers $\left(M_{r} \times 10^{-3}\right)$ are indicated on the left (Bio-Rad Laboratories, Richmond, CA). The amyloid proteins have apparent molecular masses of 6,000 7,000 and $8,000-9,000$, respectively. 


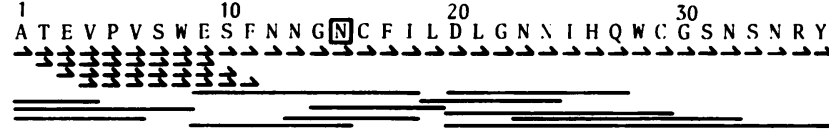

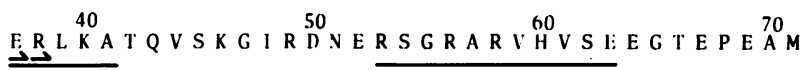

Figure 3. Primary structure of the purified larger amyloid protein of Finnish hereditary amyloidosis. The arrows below the sequence indicate automated sequence analysis from the $\mathrm{NH}_{2}$-terminal end of the intact protein, and the lines below the sequence indicate peptides derived from digestion with trypsin, endoproteinase Asp- $\mathrm{N}$, Lys-C, and Glu-C. The substitution is boxed.

ized light. Electron microscopy of the fibril preparation revealed typical nonbranching amyloid fibrils of $\sim 8-9 \mathrm{~nm}$ width (Fig. 1). Under dissociating conditions the amyloid subunit protein was eluted in gel filtration as a retarded peak, which was absent in control experiments with material extracted from nonamyloid kidney and splenic specimens. SDSPAGE of the material eluted in the retarded peak, revealed two bands with $M_{\mathrm{r}} \sim 6,000-7,000$ and 8,000-9,000, respectively (Fig. 2). Final purification of the amyloid proteins was achieved by reverse-phase HPLC.

Amino acid sequence analyses were carried out on the intact protein and the alkylated derivative. Peptide fragmentation was obtained by trypsin and by endoproteinase Asp-N, Glu-C, and Lys-C treatments. The results are summarized in Fig. 3, which shows the complete primary structure of the larger amyloid protein. By direct automated sequencing 38 amino acids of the $\mathrm{NH}_{2}$-terminus were identified; the remaining sequence of the molecule was identified by analyzing the sequences of the enzymatically derived overlapping peptides. Microheterogeneity was present at the $\mathrm{NH}_{2}$-terminal end of the molecule. In addition to the major form starting with alanine $(\sim 60 \%)$, there were minor forms starting with either threonine $(\sim 30 \%$, residue 2$)$, glutamic acid $(\sim 5 \%$, residue 3$)$ or valine $(\sim 5 \%$, residue 4$)$. In addition to the amyloid protein ending in methionine (residue 71), there were molecules that ended in alanine (residue 70 ).

The amino acid sequence of the 71-residue amyloid protein is completely homologous to the predicted sequence of human plasma gelsolin (12) in the region of amino acids 173-243 of the mature protein (or residues 200-270 of the precursor pro- tein) with one exception: at position 15 of the amyloid protein, which corresponds to residue 187 of plasma gelsolin (or 214 of the gelsolin precursor) an asparagine was found instead of an aspartic acid residue (Fig. 4). This substitution was a consistent finding in all analyses and was also present in the amyloid protein isolated from the patient's cardiac tissue. When comparing the primary structure of the amyloid protein with the other actin-modulating or -binding proteins, villin (15), severin (16), and fragmin (17), it is noted that they all have an aspartic acid residue at the position which corresponds to residue 15 (asparagine) of the amyloid protein (Fig. 4). The smaller amyloid component is a fragment of the larger component representing the $\mathrm{NH}_{2}$-terminal 53 amino acids of the molecule (Fig. 5).

Anti-gelsolin antibodies raised against a synthetic dodecapeptide, corresponding to residues 231-242 of human gelsolin, specifically stained the amyloid deposits in the diseased tissues (Fig. 6). The staining was completely abolished by absorption of the antiserum with the synthetic peptide 231-242 used for the immunization, but not by a synthetic peptide corresponding to residues 213-221. The $P_{231-242}$ antiserum did not stain normal glomerular or cardiac vascular tissue or the amyloid deposits found in primary amyloidosis (amyloid light chain) or secondary amyloidosis (amyloid A), demonstrating the specificity of the $\mathbf{P}_{\mathbf{2 3 1 - 2 4 2}}$ antiserum for Finnish hereditary amyloid.

\section{Discussion}

In the systemic forms of amyloidosis several types of amyloid proteins derived from whole or fragmented plasma precursor proteins have been identified. In primary and myeloma-associated amyloidosis, the amyloid protein is related to immunoglobulin light chains (18), in secondary amyloidosis to serum amyloid A protein (18), in haemodialysis-associated amyloidosis to $\beta_{2}$-microglobulin (19), in FAP I, II, and some related syndromes to transthyretin (20-30), and in FAP III to apolipoprotein A-I (31). The present study provides definite evidence for the unique, gelsolin nature of the amyloid in Finnish FAP, and shows that the amyloid protein is derived from a variant gelsolin molecule.

The calculated molecular weight of the amyloid protein was $8.1 \mathrm{kD}$, which is consistent with the estimate based on SDS-PAGE. The amyloid protein thus represents a fragment of the precursor gelsolin molecule $(\sim 83 \mathrm{kD})$ and is obviously formed through limited proteolysis of the precursor. In accor-

\begin{tabular}{|c|c|c|}
\hline Amyloid & in 1 & A TE $V$ P VSWESFN \\
\hline Gelsol in & 200 & A T E VPVSWESFNNGDCFILDLGNN I $\| Q W C G S N S N R$ \\
\hline Villin & 149 & 因6峟 \\
\hline Severin & 174 & 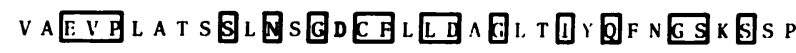 \\
\hline Fragmin & & 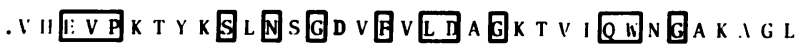 \\
\hline
\end{tabular}

Amyloid protein 36 YERLKATQVSKGIRDNERSGRARVHVSEIEGTEPEAM71 Gelsolin 235 YERLKATQVSKGIRDNERSGRARVHVSEEGTEPFAMFio Villin 184 MERDRGMTLA因ERDQERGGRT Y DG DV D G E H E A S P 219

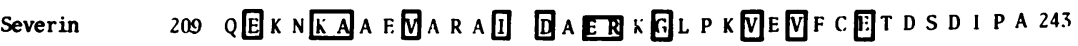
Fragmin

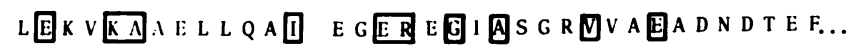

Figure 4. Comparison of the amino-acid sequence of the 71-residue amyloid protein with the deduced sequences of human plasma gelsolin precursor (12), human villin (15), severin (16), and the sequence of fragmin (17). The residues of fragmin are not numbered, because the sequence is not complete. Homologous amino acids are boxed. The amyloid protein and gelsolin sequences are identical except at position 15 of the amyloid protein; the residue is asparagine in contrast to the aspartic acid at the corresponding positions in human gelsolin. The numbering of gelsolin refers to the precursor molecule (residues 200-270 correspond to residues 173-243 of mature secreted gelsolin). 


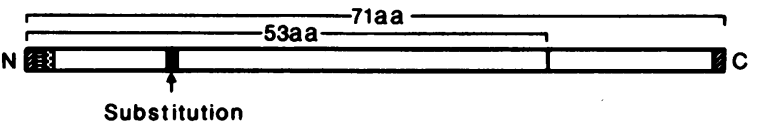

Figure 5. Schematic presentation of the renal amyloid proteins in Finnish hereditary amyloidosis. The 53-residue component is a fragment of the larger 7i-amino acid (aa) long component. The amino acid deletions at the $\mathrm{NH}_{2}$ - and $\mathrm{COOH}$-terminal ends are indicated by hatched areas.

dance with previous data (11) the $\mathrm{NH}_{2}$-terminus showed microheterogeneity, which has also been described in transthyretinrelated amyloid proteins of Swedish (23), Japanese $(24,25)$, and Appalachian (29) types of FAP and may be a reflection of the amyloid disease process.

The amino acid sequence of the amyloid protein showed identity with the predicted sequence of human gelsolin representing residues $173-243$ of the mature secreted plasma gelsolin (12) with one exception: at position 15 of the amyloid protein on asparagine was found in contrast to the predicted aspartic acid at the corresponding position (187) in normal secreted gelsolin. The asparagine-for-aspartic acid substitution was found both in the amyloid protein extracted from the kidney and the heart and was a consistent finding in the sequence analyses.

Whether the asparagine-for-aspartic acid substitution in the precursor gelsolin molecule explains a defective proteolytic processing in Finnish FAP and a subsequent polymerization of the accumulating fragments to tissue amyloid cannot be settled at present. However, this possibility seems likely, because previous studies have shown that single amino acid substitutions in the amyloid precursor proteins, transthyretin in FAP type I and II and some related syndromes (21-30), apolipoprotein A-I in FAP type III (31) and cystatin C in Icelandic hereditary amyloidosis (32), are all associated with the development of amyloid in these diseases. Moreover, we have recently demonstrated a point mutation in the gelsolin gene that is responsible for the expression of the mutant asparagine-187 gelsolin molecule in patients with Finnish FAP (13).

Gelsolin is a calcium- and polyphosphoinositide-regulated actin-modulating protein that occurs in a cytoplasmic and a secreted form $(12,33)$. Both types are derived by alternative transcriptional initiation sites and message processing from a single gene located on chromosome 9 (34). The function of circulating gelsolin has not been defined, but it may be essential
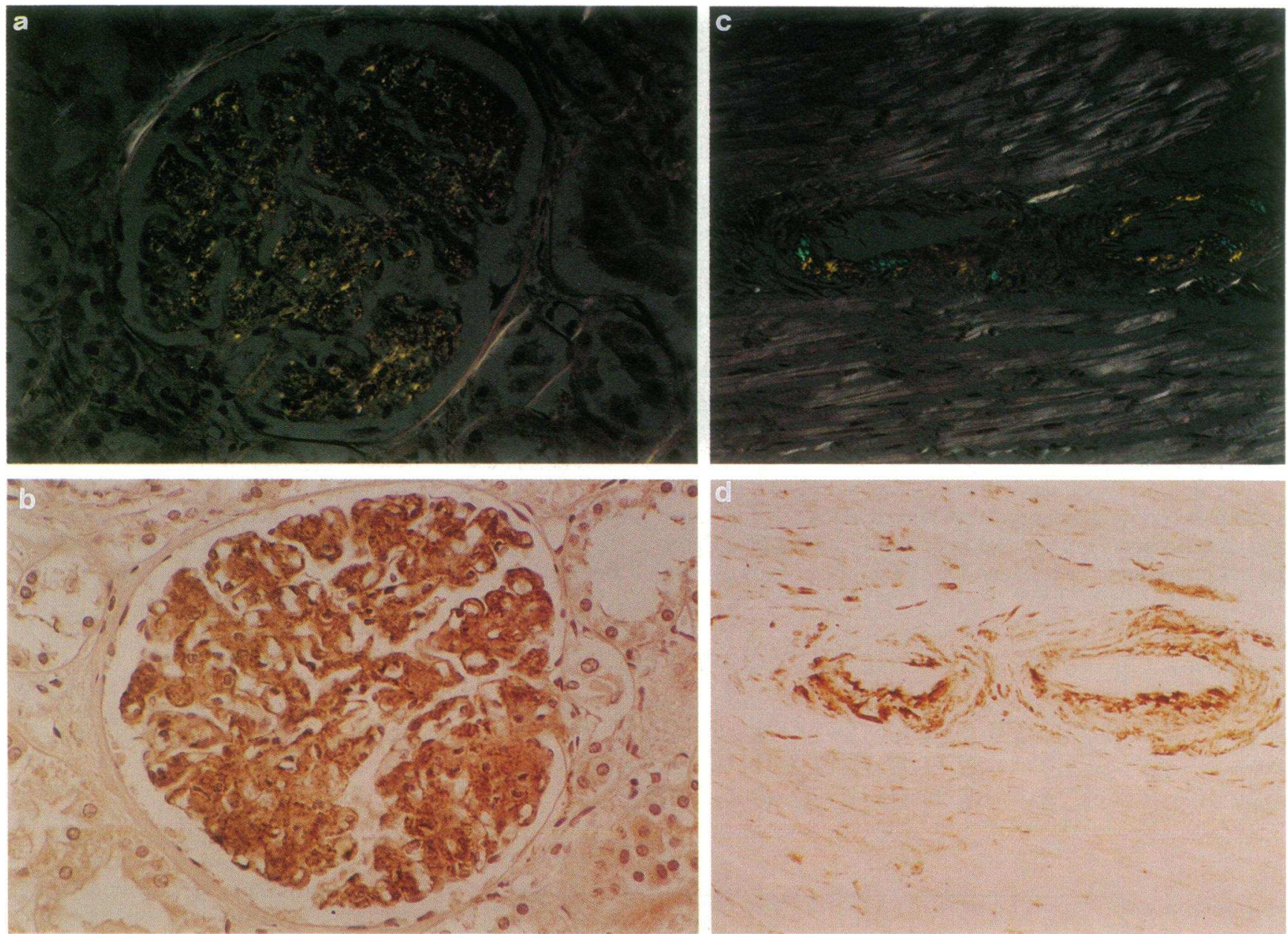

Figure 6. Immunoperoxidase staining of tissue amyloid deposits in Finnish hereditary amyloidosis with antibodies to residues 231-242 of gelsolin. (a) Dichroism of glomerular amyloid in a renal section. Congo-red staining and polarized light. (b) Adjacent section stained with the $\mathrm{P}_{\text {231-242 }}$ anti-gelsolin antibodies. Magnification, 300. (c) Dichroism of vascular amyloid in the myocardium. (d) Adjacent section stained with the $\mathrm{P}_{231-242}$ anti-gelsolin antibodies. Magnification, 150. 
for the clearance of actin filaments released into the circulation during tissue injury and cell senescence.

Recent studies (35-38) have suggested that calcium-binding to the $\mathrm{COOH}$-terminal half of gelsolin leads to a conformational change which permits the $\mathrm{NH}_{2}$-terminal half to sever actin filaments. Severing by the $\mathrm{NH}_{2}$-terminal half of gelsolin is calcium-independent, but requires the participation of two actin-binding domains located within residues 1-149 and residues 150-406. The latter peptide, which contains the amyloid protein sequence, binds to the sides of actin filaments in a polyphosphoinositide-sensitive manner. Data have also been presented that the related gelsolin fragment $150-373$ promotes the aggregation of G-actin into large complexes and filament formation. The sequence of the amyloid protein is thus part of a functional domain of the gelsolin molecule, and it may be speculated that a disturbed proteolytic degradation of this region of gelsolin and the consequent accumulation of the undegraded fragments into amyloid during fibrillogenesis may lead to disturbance in gelsolin-actin interactions.

\section{Acknowledgments}

I wish to thank Marc Baumann, Department of Medical Chemistry, University of Helsinki, for amino acid sequence analyses, Kristiina Alli and Leena Juusela for skillful technical assistance, and the Sigrid Jusélius Foundation, the Finnish Academy of Sciences, the Perklén's Foundation, and the Stockmann Foundation for financial support.

\section{References}

1. Meretoja, J. 1969. Familial systemic paramyloidosis with lattice dystrophy of the cornea, progressive cranial neuropathy, skin changes and various interna symptoms. A previously unrecognized heritable syndrome. Ann. Clin. Res. 1:314-324.

2. Meretoja, J. 1973. Genetic aspects of familial amyloidosis with corneal lattice dystrophy and cranial neuropathy. Clin. Genet. 4:173-185.

3. Meretoja, J., T. Hollmen, T. Meretoja, and R. Penttinen. 1978. Partia characterization of amyloid proteins in inherited amyloidosis with lattice corneal dystrophy and in secondary amyloidosis. Med. Biol. (Helsinki). 56:17-22.

4. Sack, G. H., K. W. Dumars, K. S. Gummerson, A. Law, and V. A. McKusick. 1981. Three forms of dominant amyloid neuropathy. The Johns Hopkins Med. J. 149:239-247.

5. Purcell, J. J., Jr., M. Rodrigues, M. I. Chishti, R. N. Riner, and J. M. Dooley. 1983. Lattice corneal dystrophy associated with familial systemic amyloidosis (Meretoja's syndrome). Ophthalmology. 90:1512-1517.

6. Darras, B. T., L. S. Adelman, J. S. Mora, R. A. Rodziner, and T. L. Munsat. 1986. Familial amyloidosis with cranial neuropathy and corneal lattice dystrophy. Neurology. 36:432-435.

7. Boysen, G., G. Galassi, Z. Kamieniecka, J. Schlaeger, and W. Trojaborg. 1979. Familial amyloidosis with cranial neuropathy and corneal lattice dystrophy. J. Neurol. Neurosurg. Psychiatry. 42:1020-1030.

8. Winkelman, J. E., J. W. Delleman, and B. J. J. Ansink. 1971. Ein hereditäres syndrom, bestehend aus peripherer polyneuropathie, hautveränderungen und gittrigen dystrophie der hornhaut. Klin. Monatsbl. Augenheilk. 159:618623.

9. Araki, S. 1986. Familial amyloidotic polyneuropathies. Portuguese, Japanese, Swedish, British, Jewish, German-Swiss and Finnish forms. In Amyloidosis. J. Marrink and M. van Rijswijk, editors. Martinus Nijhoff Publishers, Dordrecht, Netherlands. 195-218.

10. Maury, C. P. J., K. Alli, and M. Baumann. 1990. Finnish hereditary amyloidosis. Amino acid sequence homology between the amyloid fibril protein and human plasma gelsolin. FEBS (Fed. Eur. Biochem. Soc.) Lett. 260:85-87.

11. Haltia, M., F. Prelli, J. Ghiso, S. Kiuru, H. Somer, J. Palo, and B. Frangione. 1990. Amyloid protein in familial amyloidosis (Finnish type) is homologous to gelsolin, an actin-binding protein. Biochem. Biophys. Res. Commun 167:927-932.

12. Kwiatkowski, D. J., T. P. Stossel, S. H. Orkin, J. E. Mole, H. R. Colten, and H. L. Yin. 1986. Plasma and cytoplasmic gelsolins are encoded by a single gene and contain a duplicated actin-binding domain. Nature (Lond.). 323:455458.

13. Maury, C. P. J., J. Kere, R. Tolvanen, and A. de la Chapelle. 1990. Finnish hereditary amyloidosis is caused by a single nucleotide substitution in the gelsolin gene. FEBS (Fed. Eur. Biochem. Soc.) Lett. 276:75-77.
14. Maury, C. P. J., 1990. Isolation and characterization of cardiac amyloid in familial polyneuropathy type IV (Finnish): relation of the amyloid protein to variant gelsolin. Biochim. Biophys. Acta. 1096:84-86.

15. Arpin, M., E. Pringault, J. Finidori, A. Garcia, J.-M. Jeltsch, J. Vandekerckhove, and D. Louvard. 1988. Sequence of human villin: a large duplicated domain homologous with other actin-severing proteins and a unique small carboxy-terminal domain related to villin specificity. J. Cell Biol. 107:1759-1766.

16. André, E., F. Lottspeich, M. Schleicher, and A. Noegel. 1988. Severin, gelsolin and villin share a homologous sequence in regions presumed to contain F-actin severing domains. J. Biol. Chem. 263:722-727.

17. Ampe, C., and J. Vandekerckhove. 1987. The F-actin capping proteins of Physarum polycephalum: cap42(a) is very similar, if not identical, to fragmin and is structurally and functionally very homologous to gelsolin; cap42(b) is Physarum actin. EMBO (Eur. Mol. Biol. Organ.) J. 6:4149-4157.

18. Glenner, G. G. 1980. Amyloid deposits and amyloidosis. The $\beta$-fibrilloses. N. Engl. J. Med. 302:1283-1292.

19. Gejyo, F., I. Yamada, S. Odani, Y. Hirasawa, T. Shirahama, A. S. Cohen, and K. A. Schmidt. 1985. A new form of amyloid protein associated with chronic hemodialysis was identified as $\beta_{2}$-microglobulin. Biochem. Biophys. Res. Commun. 129:701-706.

20. Costa, P. P., A. S. Figueira, and F. R. Bravo. 1978. Amyloid fibril protein related to prealbumin in familial amyloidotic polyneuropathy. Proc. Natl. Acad. Sci. USA. 75:4499-4503.

21. Pras, M., E. C. Franklin, F. Prelli, and B. Frangione. 1981. A variant of prealbumin from amyloid fibrils in familial polyneuropathy of Jewish origin. $J$. Exp. Med. 154:989-993.

22. Benson, M. D. 1981. Partial amino acid sequence homology between an heredofamilial amyloid protein and human plasma prealbumin. J. Clin. Invest. 67:1035-1041.

23. Skinner, M., and A. S. Cohen. 1981. The prealbumin nature of the amyloid protein in familial amyloid polyneuropathy (FAP)-Swedish variety. Biochem. Biophys. Res. Commun. 99:1326-1332.

24. Tawara, S., M. Nakazato, K. Kangawa, H. Matsuo, and S. Araki. 1983. Identification of amyloid prealbumin variant in familial amyloidotic polyneuropathy (Japanese type). Biochem. Biophys. Res. Commun. 116:880-888.

25. Kametani, F., H. Tonoike, A. Hoshi, T. Shinoda, and S. Kito. 1984. A variant prealbumin-related low molecular weight amyloid fibril protein in familial amyloid polyneuropathy of Japanese origin. Biochem. Biophys. Res. Commun. 125:622-628.

26. Saraiva, M. J. M., S. Birken, P. P. Costa, and D. S. Goodman. 1984 Amyloid fibril protein in familial amyloidotic polyneuropathy Portuguese type. J. Clin. Invest. 74:109-119.

27. Nakazato, M., K. Kangawa, N. Minamino, S. Tawara, H. Matsuo, and S. Araki. 1984. Revised analysis of amino acid replacement in a prealbumin variant (SKO-III) as sociated with familial amyloidotic polyneuropathy of Jewish origin. Biochem. Biophys. Res. Commun. 123:921-928.

28. Dwulet, F. E., and M. D. Benson. 1984. Primary structure of an amyloid prealbumin and its plasma precursor in a heredofamilial polyneuropathy of Swedish origin. Proc. Natl. Acad. Sci. USA. 81:694-698.

29. Wallace, M. R., F. E. Dwulet, P. M. Conneally, and M. D. Benson. 1986. Biochemical and molecular genetic characteristic of a new variant prealbumin associated with hereditary amyloidosis. J. Clin. Invest. 78:6-12.

30. Dwulet, F. E., and M. D. Benson. 1986. Characterization of a transthyretin (prealbumin) variant associated with familial amyloidotic polyneuropathy type II (Indiana/Swiss). J. Clin. Invest. 78:880-886.

31. Nichols, W. C., F. E. Dwulet, J. Liepnieks, and M. D. Benson. 1988. Variant apolipoprotein AI as a major constituent of a human hereditary amyloid. Biochem. Biophys. Res. Commun. 156:762-768.

32. Levy, E., C. Lopez-Otin, J. Ghiso, D. Geltner, and B. Frangione. 1989. Stroke in Icelandic patients with hereditary amyloid angiopathy is related to a mutation in the cystatin $\mathrm{C}$ gene, an inhibitor of cysteine proteases. J. Exp. Med. 169:1771-1779.

33. Yin, H. L., D. J. Kwiatkowski, J. E. Mole, and F. S. Cole. 1984. Structure and biosynthesis of cytoplasmic and secreted variants of gelsolin. J. Biol. Chem. 259:5271-5276.

34. Kwiatkowski, D. J., C. A. Westbrook, G. A. P. Burns, and C. Morton. 1988. Localization of gelsolin proximal to ABL on chromosome 9. Am J. Hum. Genet. 42:565-572.

35. Yin, H. L., K. Iida, and P. A. Janmey. 1988. Identification of a polyphosphoinositide-modulated domain in gelsolin which binds to the sides of actin filaments. J. Cell Biol. 106:805-812.

36. Bryan, J. J. 1988. Gelsolin has three actin-binding sites. J. Cell Biol. 106:1553-1562.

37. Way, M., J. Gooch, B. Pope, and A. G. Weeds. 1989. Expression of human plasma gelsolin in Escherichia coli and dissection of actin binding sites by segmental deletion mutagenesis. J. Cell Biol. 109:593-605.

38. Kwiatkowski, D. J., P. A. Janmey, and H. L. Yin. 1989. Identification of critical functional and regulatory domains in gelsolin. J. Cell Biol. 108:17171726. 